\title{
Educational Homogamy of Married AND UNMARRIED COUPLES IN ENGLISH AND FRENCH CANADA
}

\author{
DANA Hamplová \\ CÉline Le Bourdais
}

\begin{abstract}
This study investigates the relative similarity of educational assortative mating patterns among young married and cohabiting couples using Canadian census data from 2001. It contrasts the patterns observed in Quebec with those observed elsewhere in Canada, as these regions display very different demographic trends, especially with respect to cohabitation. First, we hypothesize that the gap between married and unmarried couples will be smaller in Quebec, as cohabitation is more common in this province. Second, we suggest that the double-selection hypothesis predicting higher educational homogamy among married couples should be more appropriate to explain the behaviours observed in Canada outside of Quebec, whereas the utilitarian theory predicting higher educational homogamy among cohabiting couples should apply better to the French province situation. The results do not support our hypotheses as difference between marriage and cohabitation is rather similar in both regions and cohabitors generally display lower educational homogamy.
\end{abstract}

Résumé. Cet article examine le degré d'homogamie éducative des jeunes couples mariés et en union libre à partir des données du recensement canadien de 2001. Il compare les comportements des couples québécois à ceux observés ailleurs au Canada, compte tenu de l'évolution différente qu'ont connue ces deux régions, particulièrement en regard des unions libres. Dans un premier temps, nous faisons l'hypothèse que l'écart entre couples mariés et cohabitants sera plus faible au Québec, l'union libre étant plus répandue dans cette province. En deuxième lieu, nous suggérons que l'hypothèse de la «double-sélection» prédisant un plus haut niveau d'homogamie éducative chez les couples mariés est plus appropriée pour rendre compte des comportements observés au Canada en dehors du

* Support for this research was provided by the Social Sciences and Humanities Research Council of Canada and the McGill Canada Research Chair on Social Statistics and Family Change. An earlier version of this paper was presented at the Population Association of America 2008 Annual Meeting, Session 37: Social Mobility Across and Within Generations, New Orleans, April 17-19, 2008. The authors are grateful for the helpful comments provided by reviewers and discussants. 
Québec, alors que la théorie utilitariste prédisant une homogamie éducative plus grande parmi les couples en union libre colle davantage à la situation de la province francophone. Les résultats de l'analyse ne confirment pas nos hypothèses. L'écart qui sépare mariage et union libre est relativement semblable dans les deux régions du pays et les couples cohabitants affichent dans l'ensemble un niveau d'homogamie plus faible que leurs homologues mariés.

Tie he question "who marries whom" is an important factor in documenting the existence of social barriers as well as explaining income inequalities and their intergenerational transmission. Marriage indicates the presence of formal ties between individuals, families, and social groups; the composition of current marriages determines the amount of economic, cultural, or social resources that are available to existing households. In this respect, assortative mating patterns partly determine the family environment in which children are raised, contributing to the life opportunities opened to the next generation (for more see EspingAndersen 2007; Mare 2000, 1991; Blossfeld and Timm 2003; Kalmijn 1998; Kalmijn 1991a; Smits, Ultee, and Lammers 1998, 1999). Although many dimensions of assortative mating can be studied, we focus on selection with respect to education, as schooling is a major determinant of occupational success and cultural capital in modern societies.

Past research on educational homogamy in North America has produced mixed results, which partly reflects differences in the populations targeted and methodologies chosen (Hou and Myles 2007). Despite this diversity, there is evidence that the levels of educational homogamy have been rising in this region for several decades (Qian and Preston 1993; Hou and Myles 2007; Schwartz and Mare 2005; Mare 1991; Kalmijn 1991a; Qian 1998; Smits, Ultee, and Lammers 1998). This trend is observable not only for the absolute number of educationally homogamous marriages but also for relative measures of homogamy that control for the educational composition of the society. Increasing educational homogamy cannot, therefore, be explained solely by educational expansion; it also indicates that increasingly selective forces of attraction are at work.

It should be noted that the rising levels of educational homogamy observed among spouses and the trend towards stricter marital selection are accompanied by declining marriage rates and the increasing popularity of nonmarital cohabitation. Hence, while spouses are becoming more alike in terms of socioeconomic characteristics, a declining fraction of men and women are marrying and cohabitation is replacing marriage, at least among certain age and social groups. In spite of this development, we know relatively little about the assortative mating patterns 
of unmarried couples and the extent to which they differ from those of married couples. Studies examining the degree of educational homogamy among cohabiting couples are rare and focus mostly on the United States. Although one of the most recent studies of educational homogamy in Canada (Hou and Myles 2007) includes cohabiting couples, it does not directly compare married and unmarried unions.

This paper goes beyond prior studies conducted in North America and focuses on Canada rather than on the United States. Moreover, it contrasts Canadian regions that represent different cultural contexts and display radically different demographic behaviour, especially with respect to cohabitation. More precisely, we focus on the difference between the predominantly Francophone province of Quebec and the Anglophone provinces. In the first part of the paper, we briefly summarize main results from previous research. In the next section, we review existing theories about differences in assortative mating patterns among married and cohabiting couples; we discuss their relevance for the Canadian context and formulate specific hypotheses relevant to marital and nonmarital selection in the two observed settings. In the third part, we analyze educational homogamy by applying log-linear models to the 2001 Canadian Census data.

\section{Past Research on Differences in Education Homogamy among Married and CoHabiting Couples}

So far, the studies of educational homogamy in cohabitation (mainly from the United States) have produced mixed results. For example, Schoen and Weinick (1993) investigated the behaviour of couples aged 19-29 who began their relationship within the 24 months prior to the date of the interview. Using the National Survey of Families and Households conducted in 1987-88, they found that American cohabitors show a greater propensity to select a partner with a similar level of education than married couples do. In contrast, Blackwell and Lichter (2000) analyzed couples in which the female partner was younger than 30 years, using the Public Use Microdata Samples (PUMS) of the 1990 decennial census, and concluded that educational homogamy was higher among married couples than among cohabitors. Similarly, Jepsen and Jepsen's (2002) analyses of the 1990 PUMS revealed higher educational homogamy among married couples compared to opposite- or same-sex cohabiting couples. Blackwell and Lichter (2004) later used the National Survey of Family Growth, a US survey of noninstitutionalized population of women aged 15-44 in 1995. Contrary to their previous work, they found 
that "cohabiting couples appear to be more homogamous at higher levels of education than dating or married couples." More recently, Hamplová (forthcoming) compared cohabiting and married couples across three distinct welfare regimes using the European Social Survey from 2002 and 2004, and showed that the differences between married and unmarried couples largely depend upon the degree to which cohabitation is institutionalized in any given society.

\section{Assortative Mating in Marriage and Cohabitation - Theoretical BACKground}

In one of the first studies on assortative mating patterns in cohabitation, Schoen and Weinick (1993) suggested that cohabitation - as a "looser bond" - lacks permanence and is associated with having and rearing children less often than marriage. As a consequence, they expected cohabiting men and women to be both more active on the labour market and more likely to contribute to the household finances, giving a higher value to achieved status, i.e., to education. Schoen and Weinick therefore predicted that cohabiting couples should display greater educational homogamy and a lower tendency for women to "marry up."

Schoen and Weinick's (1993) argument can be further expanded with Brines and Joyner's (1999) work on principles of cohesion in marriage and cohabitation. Adopting utilitarian theory, they suggest that the degree of permanence and uncertainty regarding the future of the relationship shape the essential principles of the couple's cohesiveness. We hypothesize that this should have consequences for assortative mating. The marriage contract insures men and women against a total loss on their investments and thus facilitates specialization of human capital and division of labour within the couple, which does not necessarily entail sharing a similar educational level. In contrast, cohabitors' uncertainty about the future of their relationship prescribes a more cautious approach to solidarity, financial transfers, shared ownership, and joint investment in general, and renders the risks of specialization higher (Brines and Joyner 1999). Therefore, the condition most favourable to stability of cohabitation should be that of partners' equal power and status (homogamy) for a series of characteristics, such as education, occupational status, or income.

Furthermore, cohabitors' greater tendency towards higher educational homogamy might be also reinforced by the different set of values they hold compared to married individuals, i.e., their emphasis on individualism, independence, equality, and nontraditional gender roles (Surkyn and Lesthaeghe 2004; Van de Kaa 1993; Axinn and Thornton 1992; Inglehart 1990). 
Contrary to the utilitarian perspective, the double-selection approach predicts that higher educational homogamy will be found among married spouses (Blackwell and Lichter 2004; 2000). According to this perspective, the main role of cohabitation is to provide young adults with a highly selective pool of potential spouses from which they subsequently draw their future marriage partners (Blackwell and Lichter 2000). This "winnowing process" implies that individuals entering cohabiting unions may be less selective about a partner's specific characteristics than individuals entering marriage. In short, some partners are good enough to live with, but not good enough to marry. As this theory assumes that homogamy is generally the preferred status in current societies, less strict selection among cohabitors should lead to lower educational homogamy in cohabitation than in marriage.

The opposite predictions made about the level of educational homogamy in cohabitation relative to marriage apparently stem from the different assumptions about the meaning and role of cohabitation in the two approaches. The utilitarian perspective views cohabitation mainly as an alternative to marriage, i.e., a long-term intimate relationship, and explains under which conditions couples will stay together in the absence of a marriage contract. In contrast, the double-selection hypothesis assumes that cohabitation serves primarily as a trial arrangement before marriage, the good matches marry and mismatches separate.

\subsection{Cohabitation in English and French Canada}

Canada offers an excellent opportunity to test these theories, as cohabitation has reached very different levels of institutionalization across different regions. In Quebec, cohabitation has become the modal way to form a family. Nowadays, nearly half the children in Quebec are born to cohabiting parents. Elsewhere in Canada, cohabitation serves mainly as a prelude to marriage with approximately $15 \%$ of children born to an unmarried couple (Le Bourdais and Lapierre-Adamcyk 2004).

Reflecting the differences between Quebec and the rest of Canada in prevalence and respective roles of marital and cohabiting unions, we expect the observed patterns of assortative mating to vary across these regions. First, we suggest that higher levels of institutionalization and acceptance of cohabitation in Quebec should be reflected in smaller differences between married and unmarried couples with respect to assortative mating patterns.

Second, we expect that marriage will differ from cohabitation in both parts of the country in a distinct way. As a long-lasting institution in which child-bearing and child-rearing now takes place, cohabita- 
tion in Quebec has become an alternative to marriage (Le Bourdais and Lapierre-Adamcyk 2004) but without the same degree of legal protection in the case of separation. This suggests that the utilitarian perspective will appropriately predict the degree of educational homogamy among cohabitors relative to married couples in Quebec: cohabiting couples in the French province are expected to be more homogamous with respect to education than married couples. In the rest of Canada, child-bearing of cohabiting couples is not as common; where cohabitation usually functions as a "test before marriage," the double selection hypothesis is more likely to apply. In this case, we expect to find greater educational homogamy among married than unmarried couples.

Although cohabiting couples should be generally more homogamous than married couples in Quebec and less homogamous elsewhere in Canada, we do not expect the degree of relative dissimilarity between married and cohabiting couples in English and French Canada to be uniform across educational groups. Past research indicates that educational groups differ in their tendency towards homogamy (Schwartz and Mare 2005; Mare 1991) and that the relative similarity of married and cohabiting couples depends on educational level (Hamplová forthcoming; Blackwell and Lichter 2004).

Third, we expect that the relative differences between marriage and cohabitation and between English and French Canada will result not only in different levels of homogamy but that they will also directly influence assortative mating among heterogamous couples, i.e., those who marry or cohabit outside of their own group. For example, in line with past research, we expect that cohabiting women will display a lower tendency to partner up with respect to education (and cohabiting men to show a lower tendency to partner down) compared to their married counterparts (Schoen and Weinick 1993; Blackwell and Lichter 2000). However, this tendency is likely to vary across French and English Canada, going in the direction of higher similarity among Quebec couples. Finally, we are interested in examining the relative difficulty of crossing an educational barrier and partnering with someone with a different status in order to see whether cohabitors face lower or higher odds of crossing educational barriers than spouses.

\section{DATA}

To analyze partner selection with respect to education in marriage and cohabitation in Quebec and elsewhere in Canada, we use the Public Use Microdata File (PUMF) on Families from the 2001 census. The 2001 
PUMF data is based on approximately a $2.7 \%$ sample of the population enumerated in the census. Canada's territories, Yukon and the Northwest Territories, are excluded from the analysis. ${ }^{1}$

The analysis is restricted to younger couples, i.e., those in which the woman is aged $25-34$ and the age difference between partners is no more than 10 years. Three reasons justify this age restriction. First, cohabitation is a relatively new phenomenon which is more common among younger generations. Second, at age 25-34, the majority of individuals have already completed their education or are sufficiently advanced to provide useful information about their educational careers on the marriage and cohabitation market. Third, as women tend to partner with older men, we chose not to restrict the age range of men since it could lead to a disproportional representation of same-age couples. The age limits reduced the sample size to 34,293 couples $(20,902$ married and 5,419 cohabiting in English Canada; 3,562 married and 4,410 cohabiting in Quebec).

This study analyzes the stock of existing unions (for a similar approach see Hou and Myles 2007; Schwartz and Mare 2005; Smits 2003; Smits, Ultee, and Lammers 1998, 1999, 2000). First, census data do not allow us to adopt a longitudinal perspective. Second, it has been argued that prevailing unions provide a more complete picture of assortative mating principles than newly formed unions (Hou and Myles 2007; Kalmijn 1998). The overall distance between social groups is reflected not only by the rate of entry into marriage or cohabitation but also by the different levels of dissolution of heterogamous unions, as spouses and cohabitors from socially distant groups face a higher risk of breaking up. Prevailing unions are also an appropriate unit for analyzing the impact of homogamy on social inequality because they provide a better picture of the resources available in existing households (Schwartz and Mare 2005).

Table 1 presents the percentage of cohabiting couples among all couples living together across Canadian provinces. The left portion of the table displays the percentage of the unions in the unrestricted sample; the right portion gives the percentage of cohabiting couples after the age restriction was imposed. In 2001, cohabitation constituted the modal way of conjugal life among young Quebecers, as only $44.7 \%$ of young couples in the province were married. In contrast, the majority of young couples residing elsewhere in Canada lived in married unions. The highest pro-

1. There were only 504 couples from the mentioned territories in the 2001 PUMF. They did not follow the general pattern typical of the Anglophone provinces and the proportion of cohabiting couples was relatively high $(33.9 \%$ in 2001). This is probably due to their specific population structure, e.g., high number of individuals from the First Nations. 
Table 1. Percentages of Cohabiting Couples by Province and Year

\begin{tabular}{lcc}
\hline & All Couples & Young Couples* \\
\hline Newfoundland & 11.3 & 25.3 \\
Prince Edward Island & 11.4 & 23.6 \\
Nova Scotia & 13.7 & 26.0 \\
New Brunswick & 15.4 & 28.4 \\
Quebec & 30.2 & 55.3 \\
Ontario & 11.0 & 18.8 \\
Manitoba & 11.7 & 20.8 \\
Saskatchewan & 11.3 & 19.1 \\
Alberta & 13.5 & 21.3 \\
British Columbia & 13.1 & 22.1 \\
N of cohabitants & 31,134 & 9,829 \\
Total N of couples & 190,299 & 34,293 \\
\hline
\end{tabular}

Source: Census (PUMF) 2001

* Women aged 25-34 and age difference between partners no more than 10 years

portion of spouses among young couples was found in the province of Saskatchewan (80.9\%) and the lowest in New Brunswick (71.6\%).

In the PUMF data, we were able to identify five categories of formal education:

1. No formal training: no high school certificate and no other training or trade certificate. ${ }^{2}$

2. Some training: no high school certificate but other training or trade certificate. $^{3}$

3. High school: high school certificate but no other training.

4. Some postsecondary education: post-high school training but no college diploma. ${ }^{4}$

5. University: bachelor degree or higher.

These categories are broad enough to overcome the existing differences across the various provincial educational systems (e.g., shorter duration of high school in Quebec) but at the same time they take into account the key milestones of the various provincial educational systems.

To analyze the educational assortative mating behaviour of married and unmarried couples in English and French Canada, the data were

2. The category includes people without high school (secondary) certificate and without formal training.

3. The category includes individuals without high school (secondary) certificate but with some other formal education (trades certificate or other nonuniversity training).

4. The category includes everybody who declared having some postsecondary training but not obtaining a university degree. 
cross-classified into a four-way table: Man's education x Woman's education x Type of union x Region ( 5 x 5 x 2 × $2-$ see Table 2). Man's and woman's education is classified into the five categories described above; the type of union distinguishes between married and cohabiting unions; and the region variables differentiate between Quebec and the other Canadian provinces.

\subsection{Descriptive statistics}

Table 2 shows the distribution of men's and women's education by region and type of union. The raw percentages presented in Table 2 suggest two findings. First, cohabitations are generally less homogamous

Table 2. Distribution (in percent) of Canadian Couples by Men's and Women's Education, Union Type and Region of Residence

\begin{tabular}{|c|c|c|c|c|c|c|c|c|c|c|c|c|}
\hline \multicolumn{13}{|c|}{ Canada outside of Quebec } \\
\hline \multirow{3}{*}{$\begin{array}{l}\text { Man's } \\
\text { educa- } \\
\text { tion }\end{array}$} & \multicolumn{6}{|c|}{ Marriage } & \multicolumn{6}{|c|}{ Cohabitation } \\
\hline & \multicolumn{6}{|c|}{ Woman's education } & \multicolumn{6}{|c|}{ Woman's education } \\
\hline & $\begin{array}{c}\text { No } \\
\text { train- } \\
\text { ing }\end{array}$ & $\begin{array}{c}\text { Train- } \\
\text { ing }\end{array}$ & $\begin{array}{c}\text { High } \\
\text { school }\end{array}$ & $\begin{array}{c}\text { Post- } \\
\text { sec- } \\
\text { ondary }\end{array}$ & $\begin{array}{l}\text { Uni- } \\
\text { ver- } \\
\text { sity }\end{array}$ & Total & $\begin{array}{c}\text { No } \\
\text { train- } \\
\text { ing }\end{array}$ & $\begin{array}{c}\text { Train- } \\
\text { ing }\end{array}$ & $\begin{array}{c}\text { High } \\
\text { school }\end{array}$ & $\begin{array}{c}\text { Post- } \\
\text { sec- } \\
\text { ondary } \\
\end{array}$ & $\begin{array}{l}\text { Uni- } \\
\text { ver- } \\
\text { sity }\end{array}$ & Total \\
\hline $\begin{array}{l}\text { No } \\
\text { training }\end{array}$ & 7.1 & 1.9 & 1.9 & 3.6 & 0.8 & 15.3 & 9.1 & 3.4 & 2.6 & 5.7 & 0.7 & 21.5 \\
\hline Training & 2.0 & 3.8 & 1.1 & 2.9 & 1.2 & 11.0 & 3.0 & 4.4 & 1.1 & 3.7 & 1.4 & 13.5 \\
\hline $\begin{array}{l}\text { High } \\
\text { school }\end{array}$ & 1.0 & 0.8 & 3.9 & 5.4 & 1.2 & 12.3 & 1.8 & 1.1 & 3.5 & 6.0 & 1.6 & 13.9 \\
\hline $\begin{array}{l}\text { Postsec- } \\
\text { ondary }\end{array}$ & 1.6 & 1.8 & 4.3 & 21.5 & 7.9 & 37.0 & 2.7 & 2.2 & 3.8 & 18.4 & 7.5 & 34.6 \\
\hline $\begin{array}{l}\text { Univer- } \\
\text { sity }\end{array}$ & 0.4 & 0.8 & 0.9 & 6.0 & 16.2 & 24.4 & 0.2 & 0.4 & 0.6 & 4.2 & 11.1 & 16.5 \\
\hline Total & 12.1 & 9.1 & 12.0 & 39.4 & 27.4 & 100.0 & 16.9 & 11.4 & 11.5 & 37.8 & 22.3 & 100.0 \\
\hline $\begin{array}{l}\text { Sum of } \\
\text { diagonals }\end{array}$ & 52.5 & & & & & & 46.5 & & & & & \\
\hline Gamma & 0.65 & & & & & & 0.60 & & & & & \\
\hline \multicolumn{13}{|c|}{ Quebec } \\
\hline $\begin{array}{l}\text { No } \\
\text { training }\end{array}$ & 6.0 & 1.6 & 2.0 & 4.1 & 0.8 & 14.6 & 7.6 & 2.0 & 2.5 & 6.3 & 1.3 & 19.7 \\
\hline Training & 1.5 & 3.5 & 1.1 & 2.6 & 1.6 & 10.3 & 1.4 & 4.0 & 1.3 & 3.9 & 1.7 & 12.4 \\
\hline $\begin{array}{l}\text { High } \\
\text { school }\end{array}$ & 1.4 & 1.2 & 4.1 & 4.8 & 0.8 & 12.3 & 1.5 & 1.3 & 3.0 & 4.9 & 1.3 & 12.0 \\
\hline $\begin{array}{l}\text { Postsec- } \\
\text { ondary }\end{array}$ & 1.8 & 2.2 & 3.5 & 21.5 & 7.8 & 36.9 & 2.6 & 2.3 & 2.6 & 21.6 & 8.1 & 37.2 \\
\hline $\begin{array}{l}\text { Univer- } \\
\text { sity }\end{array}$ & 0.3 & 1.1 & 0.5 & 6.7 & 17.3 & 25.9 & 0.2 & 0.9 & 0.2 & 4.8 & 12.6 & 18.6 \\
\hline Total & 11.1 & 9.7 & 11.2 & 39.6 & 28.4 & 100.0 & 13.4 & 10.5 & 9.7 & 41.4 & 25.1 & 100.0 \\
\hline $\begin{array}{l}\text { Sum of } \\
\text { diagonals }\end{array}$ & 52.4 & & & & & & 48.8 & & & & & \\
\hline Gamma & 0.64 & & & & & & 0.58 & & & & & \\
\hline
\end{tabular}

Source: Census (PUMF) 2001 
than marriages. Second, the difference between marriage and cohabitation is smaller in the French province. For example, in English Canada, the proportion of married couples in which both spouses have the same education was 6 percentage points higher than the proportion of their cohabiting counterparts (52.5\% versus 46.5\%). In Quebec, the difference between married and cohabiting couples was 3.6 percentage points. The lower levels of educational homogamy among unmarried couples seems to be driven by cohabiting women with higher education who tend to live in less homogamous partnerships than their married counterparts. In English Canada, 59\% of married and 50\% of cohabiting university educated women live in a homogamous partnership. ${ }^{5}$ In Quebec, the trend is similar (61\% and 50\% respectively).

However, the descriptive statistics need to be treated with caution as they are influenced by the marginal distributions of men's and women's education. In the next section, we thus turn to log-linear models to control for differences in the marginal distributions and analyze the observed patterns after controlling for the educational structure.

\section{4. Мethod}

Log-linear models are commonly used to investigate homogamy patterns in marriage and cohabitation. This method distinguishes between patterns that result from the marginal distributions of male and female characteristics (the frequency of any cell is determined by the size of its associated marginal totals, i.e., it reflects the relative size of the corresponding educational group), and those that reflect the association observed between the partners' traits, for example the tendency to partner within the same group (Powers and Xie 2000).

Specifically, this paper uses "homogamy models" and "crossing models" (Schwartz and Mare 2005; Powers and Xie 2000; Mare 1991; Johnson 1980; Blackwell and Lichter 2004; Kalmijn 1991b). These models will allow us to differentiate between the tendency to partner within the same group, and social distance, i.e., the tendency to partner with individuals with relatively similar status compared to those with very different status (Kalmijn 1991b). In general, crossing models reflect the idea that people have to cross social barriers if they want to partner with somebody from a different social category. Unlike uniform association models, the crossing models assume that the different barriers separating social groups represent varying degrees of difficulty for crossing. In this

5. We obtain $59 \%$ by relating the proportion of women with a university degree who married a man with a similar level of education $(16.2 \%)$ to all married women having such a degree (27.4\%). 
sense, they "reveal which educational differences between prospective spouses are serious barriers to intermarriage and which differences are relatively permeable boundaries" (Mare 1991).

To describe patterns in a table, log-linear models employ a set of parameters that determine the estimated frequency of each cell (i.e., the estimated frequency of each cell can be viewed as a sum of these parameters). ${ }^{6}$ Each of our models controls for marginal totals by including parameters reflecting the number of men who achieved a specific educational level and parameters reflecting the number of women who achieved a specific educational level. A model consisting exclusively of those two sets of parameters would be an independence model ${ }^{7}$ that allows for dissimilarity in the row and column marginals ${ }^{8}$ (for more, see Powers and Xie 2000). To describe the actual association between men's and women's education, four additional type of parameters are used. Their specification and location is shown in Table 3 .

Homogamy parameters refer to the cells on the main diagonal and indicate to what extent diagonal cells are larger than they would be if a man's and a woman's education were independent. Two types of homogamy parameters are employed in our models. First, Homog is a single parameter assigned to every cell on the diagonal. The value of this single parameter Homog measures the general tendency towards homogamy.

Second, the parameters Diag1-Diag5 differentiate the specific cells on the diagonal (Diagl - both partners have no formal education; Diag2 - both partners have some training; Diag3 - both partners have high school; Diag4 - both partners have some postsecondary education; Diag 5 - both partners have university degree). Parameters Diag 1Diag5 indicate the extent of homogamy for each educational level. Using those five diagonal parameters in the model means that diagonal cells are fitted exactly: values of these parameters are set to a value that makes the estimated and observed frequencies equal.

The hypergamy parameter Hyper is assigned to cells that lie under the main diagonal and indicates whether - in the absence of homogamy - it is the man who has achieved a higher level of education (see Table 3). This parameter shows to what extent frequencies in cells under the main diagonal are, on average, larger than we could expect under independence.

6. The estimated cell frequency is $\mathrm{F}_{\mathrm{ij}}=\exp \left(\mu+\mu_{\mathrm{i} \text {-row }}+\mu_{\mathrm{j} \text {-column }}+\mu_{\mathrm{i} \text {-row }} *_{\text {j-column }}\right)$ where $\mu$ is a constant, $\mu_{\mathrm{i} \text {-row }}$ is a marginal effect of $\mathrm{i}^{\text {th }}$ row, $\mu_{\mathrm{j} \text {-column }}$ is a marginal effect of $\mathrm{j}^{\text {th }}$ column, and $\mu_{\mathrm{i} \text {-row } w_{j} \text {-column }}$ describes an association between a row and a column variable.

7. The estimated cell frequencies in an independence model are given as exp (row parameter + column parameter + constant).

8. If an educational category is small, the corresponding cells should be smaller even in the absence of any relationship (Powers and Xie 2000). 
Table 3. Overview of Estimated Parameters

\begin{tabular}{lccccc}
\hline \multirow{2}{*}{$\begin{array}{l}\text { Man's } \\
\text { education }\end{array}$} & No training & Training & High & Postsecondary & University \\
\cline { 2 - 6 } No training & Homog & - & - & - & - \\
Training & - & Homog & - & - & - \\
High & - & - & Homog & - & - \\
Postsecondary & - & - & - & Homog & - \\
University & - & - & - & - & Homog \\
\hline No training & Diag1 & - & - & - & - \\
Training & - & Diag2 & - & - & - \\
High & - & - & Diag3 & - & - \\
Postsecondary & - & - & - & Diag4 & - \\
University & - & - & - & - & Diag5 \\
\hline No training & - & cr1 & cr1+cr2 & cr1+cr2+cr3 & $\mathrm{cr} 1+\mathrm{cr} 2+\mathrm{cr} 3+\mathrm{cr} 4$ \\
Training & $\mathrm{cr} 1$ & - & $\mathrm{cr} 2$ & $\mathrm{cr} 2+\mathrm{cr} 3$ & $\mathrm{cr} 2+\mathrm{cr} 3+\mathrm{cr} 4$ \\
High & $\mathrm{cr} 1+\mathrm{cr} 2$ & $\mathrm{cr} 2$ & - & $\mathrm{cr} 3$ & $\mathrm{cr} 3+\mathrm{cr} 4$ \\
Postsecondary & $\mathrm{cr} 1+\mathrm{cr} 2+\mathrm{cr} 3$ & $\mathrm{cr} 2+\mathrm{cr} 3$ & $\mathrm{cr} 3$ & - & $\mathrm{cr} 4$ \\
University & $\mathrm{cr} 1+\mathrm{cr} 2+\mathrm{cr} 3+\mathrm{cr} 4$ & $\mathrm{cr} 2+\mathrm{cr} 3+\mathrm{cr} 4$ & $\mathrm{cr} 3+\mathrm{cr} 4$ & $\mathrm{cr} 4$ & - \\
\hline No training & - & - & - & - & - \\
Training & Hyper & - & - & - & - \\
High & Hyper & Hyper & - & - & - \\
Postsecondary & Hyper & Hyper & Hyper & - & - \\
University & Hyper & Hyper & Hyper & Hyper & - \\
\hline
\end{tabular}

Finally, crossing parameters indicate the distance between ondiagonal and off-diagonal cells. They reflect the fact that the larger the distance separating a man's and woman's education, the lower are their odds of partnering. The parameter Crossing $1(\mathrm{Cr} 1)$ indicates the barrier that separates the educational group 1 and group 2 ("no training" and "training"), the parameter Crossing 2 (Cr2) the barrier separating the second and the third educational categories ("training" and "high school"), the parameter Crossing 3 (Cr3) the barrier between the third and the fourth educational groups ("high school" and "postsecondary"), and the parameter Crossing 4 (Cr4) the barrier between the fourth and the fifth categories ("postsecondary" and "university"). The wider the gap existing between the partners' levels of education, the more barriers partners have to cross. For example, an individual with no training who marries a person with a high school diploma has to cross two barriers: the first one between "no training" and "training" $(\mathrm{Cr} 1)$ and the second one between "training" and "high school" $(\mathrm{Cr} 2)$.

The estimates are based on tables standardized to 20,000 couples per region, or 10,000 cohabitations and 10,000 marriages per region. The advantage of using the standardized numbers (Ns) of 10,000 unions is that it prevents larger data sets from having a disproportional influence on the model selection process (Ultee and Luijkx 1990; Erikson and 
Goldthorpe 1987). Standardized cell Ns were calculated as $\mathrm{N}_{\mathrm{st}}=\left(\mathrm{N}_{\text {orig }} /\right.$ $\left.\mathrm{N}_{\text {total }}\right) * 10,000$, where $\mathrm{N}_{\mathrm{st}}$ is the new standardized number of cases in the specific cell, $\mathrm{N}_{\text {orig }}$ is the original number of cases in this cell and $\mathrm{N}_{\text {total }}$ is the total number of cases in the table. The standardized cells can also be obtained by multiplying the percentages from Table 2 by 100 .

\section{Results: Log-Linear Models ${ }^{9}$}

Our analyzes are based on strategy applied by Schwartz and Mare (2005). First, we saturate the overall interaction between man's and woman's education, irrespective of their marital status and place of residence (parameter man's education*woman's education). In the next steps, we add the homogamy measures and crossing parameters. Homogamy models estimate the odds of having a partner with the same education while crossing models analyze the differences in the distance between educational groups in the absence of homogamy. The described strategy is appropriate if our main interest is to show trends (or differences) in the association as it allows us to focus on similarity or dissimilarity rather than overall levels (Schwartz and Mare 2005).

Table 4 provides the specification and goodness-of-fit statistics of the tested log-linear models. Model selection is based on BIC - Bayesian Information Criterion (Powers and Xie 2000; Raftery 1995) because of the large sample size..$^{10}$ Generally, negative BIC signifies that the model replicates the pattern in the table adequately and the more negative BIC is, the better the fit of the model (see also Kass and Raftery 1995; Kuha 2004). ${ }^{11}$

Model 1 in Table 4 controls for the full association between man's and woman's education and serves as a baseline model. Model 2 adds an interaction term between homogamy and type of union, allowing the estimated frequencies of the diagonal cells in a portion of the table describing marriage to take different values than those in the portion of the table describing cohabitation. Model 2 employs a single homogamy parameter Homog (indicating whether the cell is on the main diagonal) and tests whether spouses and cohabitors differ in their overall tendency to have

9. John Hendrickx's Desmat ado-file for Stata is used for estimations.

10. Value of BIC for each model is counted as $B I C=G^{2}-[d f * \ln (N)] . N=40,000$.

11. Raftery (1995) suggested the following rule of thumb for model evaluations: BIC difference (difference in BICs between two models) 0-2 is weak evidence, difference 2-6 is positive evidence, difference $6-10$ is strong evidence, and difference more than 10 is very strong evidence. BIC does not work with the traditional concept of statistical significance (p-values), which is why "strength of evidence" is reported. However, comparison of BIC values with p-values suggests that with large samples any difference in BIC indicates that the difference can be considered statistically significant. 
Table 4. Log-linear Models of the Association between Man's and Woman's Education

\begin{tabular}{llrrr}
\hline & & $G 2$ & $d f$ & \multicolumn{1}{c}{$B I C$} \\
\hline M1 & EduM*EduF & 991.04 & 75 & 196.30 \\
M2 & EduM*EduF + Homog*U & 896.56 & 73 & 123.00 \\
M3 & EduM*EduF + Homog*Qc & 984.73 & 73 & 211.17 \\
M4 & EduM*EduF + Homog*U*Qc & 884.47 & 69 & 153.30 \\
\hline M5 & EduM*EduF + Diag*U & 696.83 & 69 & -34.34 \\
M6 & EduM*EduF + Diag*U*Qc & 625.19 & 57 & 21.18 \\
M7 & EduM + EduF + Diag*U & 3291.78 & 80 & 2444.05 \\
M8 & EduM + EduF + Diag*U*Qc & 3220.14 & 68 & 2499.57 \\
\hline M9 & EduM*EduF + Diag*U + Hyper*U & 624.67 & 68 & -95.90 \\
M10 & EduM*EduF + Diag*U + Hyper*U*Qc & 607.43 & 64 & -70.75 \\
\hline M11 & EduM*EduF + Homog*U + Hyper*U & 824.40 & 72 & 61.45 \\
M12 & M11 + Cross*U & 627.24 & 68 & -93.34 \\
M13 & M11 + Cross*U*Qc & 485.89 & 58 & -128.72 \\
M14 & M13 - Cross4*U*Qc & 494.68 & 60 & -141.12 \\
M15 & M14 - Homog*U & 526.96 & 61 & -119.44 \\
\hline
\end{tabular}

Source: Census (PUMF) 2001

EduM - man's education,

EduF - woman's education,

Qc - Quebec,

Homog - cells on the main diagonal (1 parameter),

Diag - cells on the main diagonal (5 parameters),

$\mathrm{Y}-$ year,

$\mathrm{U}$ - type of union,

Hyper - hypergamy parameter,

$\mathrm{Cr} 1$ - crossing parameters

a partner with the same level of education. The interaction term between homogamy parameter and type of union brings about a large decrease in BIC [BIC difference $=73(196.3-123.0=73.3)]$ which indicates that marital and cohabiting partnerships significantly differ with respect to educational homogamy.

Model 3 considers whether English and French Canadians differ in their overall tendency towards homogamy (measured by an interaction term between a single homogamy parameter and region: homogamy*Quebec). However, an increase in BIC does not support this expectation. Finally, Model 4 tests whether the difference between marriage and cohabitation varies across English and French Canada; whether cohabiting and married couples in Quebec are more alike than those in English Canada. The BIC measure indicates that Model 4 is overspecified compared to Model 2 which holds the difference between marriage and cohabitation constant 
across regions. This finding suggests that if we consider an overall measure of homogamy (a simple parameter signalling on- and off-diagonal cells), cohabitors in French Canada differ from spouses as much as those living in English Canada.

As this single homogamy parameter ignores important variation across educational levels, Models 5-10 use five diagonal-specific parameters Diag1-Diag5 as a measure of homogamy (see Table 3 for the exact meaning of these parameters) and fit the diagonal exactly. Model 5 which includes interaction terms between the diagonal cells and union (Diag1*Union, Diag2*Union, Diag3*Union, Diag4*Union, Diag5*Union) assumes that spouses and cohabitors differ in their tendency towards homogamy and that the magnitude of the differences is not the same across different educational categories. Model 5 has a considerably better overall fit than Model 2 as BIC decreased by 157 $[123.0-(-34.3)=157.3)]$ confirming that the difference between marital and cohabiting unions depends on the level of education.

The next model (Model 6 in Table 4) includes a three-way interaction term between the cells on the main diagonal, type of union, and regions (Diag1-5*Union*Quebec). This model not only assumes that marriage and cohabitation are different in terms of educational homogamy but also tests whether cohabiting and married couples are more similar in Quebec than in English Canada. The three-way interaction does not, however, improve the fit and the increase in BIC suggests that the model is overspecified.

Finally, Models 7 and 8 test the significance of the same interaction effects (Diag1-5*Union*Quebec) without saturating the overall interaction between man's and woman's education, leaving out the interaction between man's education and woman's education. Again, the three-way interaction between cells on the main diagonal, union, and region does not seem to be significant.

The analysis above shows that if we look at homogamy measures, we do not find any support for the hypothesis stating that cohabiting and married couples are more similar in Quebec compared to the rest of Canada. However, the relationship between partners' education is not confined only to the diagonal but is also reflected in the assortative mating patterns of heterogamous couples. In the next step, we thus model the statistical association outside of the main diagonal, looking at assortative mating in the absence of homogamy.

First, we relax the assumption postulating that marrying or cohabiting out of one's own educational group is symmetrical for men and women. A hypergamy parameter Hyper is added to the equation expressing that - in the absence of homogamy - women tend to partner up 
with respect to education while men tend to partner with women who achieved lower levels of education than they did themselves. In other words, the estimated frequencies in the cells under the diagonal are allowed to be larger than they would be if men and women did not differ in their propensity to partner up.

Model 9 is an extension of Model 5 that adds the hypergamy parameter and lets it vary across unions (Hyper*Union). In this model, the hypergamy parameter that is assigned to under-diagonal cells in the "marriage portion" of the table can take a different value than the one assigned to the "cohabitation portion" of the table. The inclusion of the union-specific hypergamy measure improves the model significantly (see the difference in BIC of Model 5 and 9), indicating that married and cohabiting women do not partner up to the same extent (and, correspondingly, married and cohabiting men differ in their tendency to partner down).

Model 9 kept the interaction term between hypergamy and union uniform across both regions and thus ignored that married and cohabiting couples in Quebec might not differ as much in terms of hypergamy as those living in English Canada. The following model (Model 10) relaxes this assumption and allows the gap between married and cohabiting couples to be significantly different in English Canada from that in Quebec. The addition of a three-way interaction term between Hypergamy*Union*Quebec in Model 10 does, however, increase BIC [-95.9 versus -70.8]. We thus conclude that the difference between spouses and cohabitors with respect to hypergamy is similar in both parts of the country.

Models 11-15 look at the off-diagonal patterns in greater detail and turn to crossing parameters (see Table 3). Model 11 serves as a baseline model for comparison of crossing models (using a single union-specific homogamy parameter Homog*Union and union-specific hypergamy measures Hyper*Union). Model 12 adds interaction terms between crossing parameters and union types ( $\mathrm{Cr} 1-4^{*}$ Union $)$ which test whether spouses and cohabitors significantly differ in their odds of crossing barriers separating the educational groups. The interaction term considerably improves the overall model fit (BIC of Model 11 - BIC of Model 12 $=154$ ). Therefore, we conclude that married and cohabiting couples do not face the same odds of educational interpartnering.

Model 13 adds three-way interaction terms ( $\mathrm{Cr} 1-4^{*}$ Union*Quebec) between crossing*union*region, testing whether the difference between marriage and cohabitation varies across English and French Canada. The inclusion of these interaction terms improves the model significantly, which suggests that the gap between cohabitors and spouses depends on 
whether they live in Quebec or in the rest of Canada. However, inspection of the specific interaction terms suggested that the three-way interaction for the fourth crossing parameter is not significant ( $\mathrm{Cr} 4^{*}$ Union*Quebec). Therefore, Model 14 drops this term and this results in significantly better fit $(\mathrm{BIC}=-141)$. We must thus conclude that while the relative difference between marriage and cohabitation in the odds of crossing educational barriers varies across Canadian regions, this does not apply to the highest barrier. Finally, Model 15 omits the union-specific homogamy parameters. This model does not fit the data as well as Model 14, but it allows us to focus on the interpretation of the crossing parameters.

\subsection{Interpretation of homogamy parameters}

First, we report results for the overall level of homogamy, i.e., the overall tendency to partner within the same educational group. Our estimates are based on Model 2 from Table 4 as this model shows the best fit from all the models using the single homogamy parameter. The estimated value for the homogamy parameter in Model 2 is 1.154 and the estimated value for the interaction term between homogamy and union type is -0.195 (data not shown). This estimate indicates that cohabiting couples are generally less homogamous than spouses. Specifically, the odds ${ }^{12}$ of partnering within the same educational group as opposed to partnering outside of the group are 3.2 for married couples $[\exp (1.154)=3.17]$ and 2.6 for cohabiting couples $[\exp (1.154-0.195)=2.60]$. This estimate applies to both English and French Canada. If the interaction between homogamy parameters and union type was allowed to vary across regions (Model 4 in Table 4), the difference between marriage and cohabitation would be weaker by $10 \%$ in Quebec; however, the difference between Quebec and the rest of Canada was not statistically significant (see BICs of Model 2 and Model 4 in Table 4).

Even though the overall level of homogamy points out to some general tendencies displayed by spouses and cohabitors, we cannot ignore the fact that the inclination to form homogamous unions is not uniform across educational classes (compare Model 5 and Model 2 in Table 4). In the next step, homogamy parameters for each educational group are considered separately. The estimates are based on Model 8 that allows these parameters to take different values for married and cohabiting unions and the differences between marriage and cohabitation to vary across Canada (Model 8 includes 3-way interactions diagonal*union*region).

12. Odds are defined as "a probability of a success" versus "probability of failure" (Agresti 2002). In our case, the odds 3.2 means that the couples are 3.2 times more likely to marry somebody with the same educational level than somebody who achieved a different level of schooling. 
Figure 1 reports estimated odds of homogamy - partnering within the same educational level - and Figure 2 shows the estimated odds ratio of homogamy for spouses and cohabitors. These figures document three findings. First, it is evident that individuals with the lowest and especially those with the highest education form the most homogamous groups (see Figure 1). Second, the largest difference between marriage and cohabitation is found among university graduates (see Figures 1 and 2). Third, the effect of the union type (marriage versus cohabitation) is relatively similar in English and French Canada (the differences are not large enough to be considered statistically significant, see Figure 2 and fit statistics of Models 7 and 8 in Table 4).

Figure 1. Odds of Homogamy for Married and Cohabiting Couples in English and French Canada

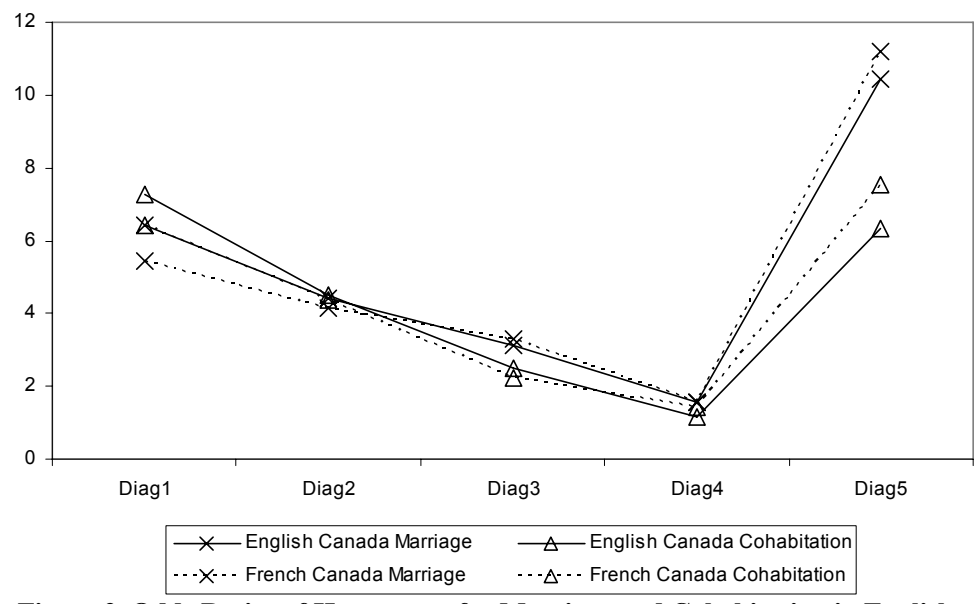

Figure 2. Odds Ratios of Homogamy for Marriage and Cohabitation in English and French Canada

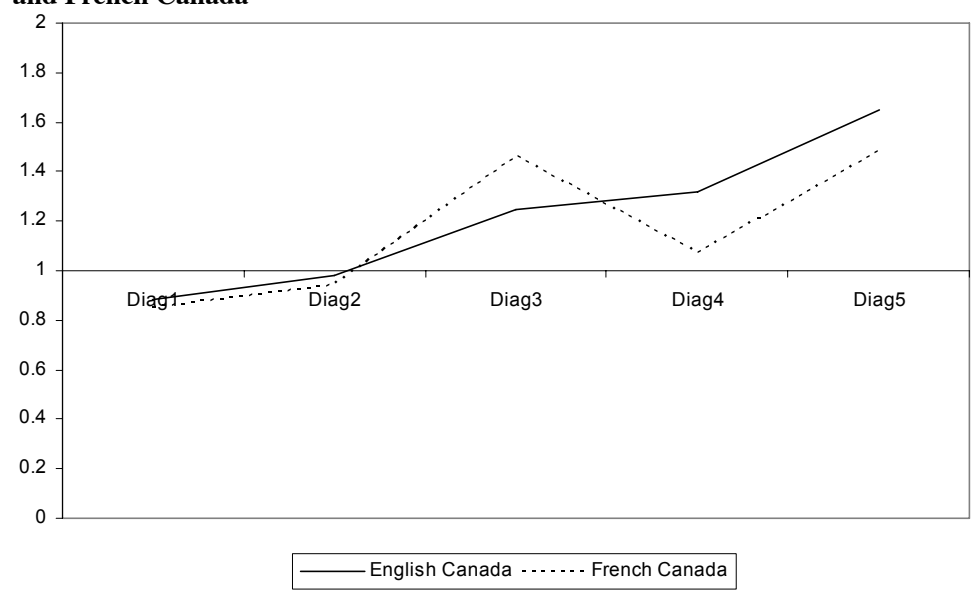




\subsection{Interpretation of crossing parameters}

The homogamy parameters are informative as they describe the odds of living in a homogamous partnership, net of the marginal distribution of men's and women's level of education. However, one should note that homogamy parameters cannot fully capture the patterns of educational assortative mating since they ignore the relative proximity of the educational groups. In this section, we turn to the interpretation of the crossing parameters that indicate how likely it is - in the absence of homogamy - to marry or cohabit with someone from a different educational group. The estimates are based on Model 15 from Table 4 .

Because our model is asymmetrical with respect to sex (men and women are not expected to have the same odds of partnering up or down the educational ladder) crossing parameters under and above the main diagonal must be adjusted for the hypergamy. The estimated hypergamy parameters vary across union type (hypergamy parameter $=0.396$ for marriage and 0.217 for cohabitation; see lower part of Table 5), which indicates that cohabiting women have lower chances for upward mobility than married women. The conversion of the hypergamy parameters into odds indicates that married women have $49 \%$ higher odds of marrying up than having a husband with lower education $[\exp (0.396)=1.49]$. Cohabiting women have $24 \%$ higher odds of partnering up [ $\exp (0.217)$ $=1.24]$ than living with a man who has achieved a lower level of education. We expected the difference between marriage and cohabitation to be smaller in Quebec. However, the 3-way interaction term between union type, hypergamy parameter, and region was not found to be significant (see Models 9 and 10 in Table 4). We thus conclude that the gap between marriage and cohabitation with respect to hypergamy in Quebec does not significantly differ from that in the rest of Canada.

The hypergamy parameters are added to crossing parameters under the main diagonal in the following manner. The value of the first crossing parameter Crossing 1 for married couples in English Canada was found to be equal to -0.591 . For couples in which the man has achieved a higher educational level than the woman, the hypergamy parameter is added to the crossing parameter $(-0.591+0.396=-0.195)$. In this case, the couple's odds of crossing the first educational barrier are 0.82 [exp $(-0.195)=0.82$; see the upper panel of Table 5]. Above the diagonal, for couples in which women have obtained more education, the hypergamy parameter equals $0(-0.591+0=-0.591)$. In this case, the couple's odds of crossing the first educational barrier are $0.55[\exp (-0.591)=0.55]$.

Table 5 reports the estimated odds of crossing educational barriers adjusted for hypergamy parameters. This table shows that the highest 
Table 5. Odds of Crossing Educational Barriers by Sex, Region, and Type of Union

\begin{tabular}{|c|c|c|c|c|c|}
\hline \multicolumn{6}{|c|}{ Canada outside of Quebec } \\
\hline \multirow[b]{2}{*}{ Man's education } & \multicolumn{5}{|c|}{ Woman's education } \\
\hline & No training & Training & High School & Postsecondary & University \\
\hline \multicolumn{6}{|l|}{ Marriage } \\
\hline No training & - & 0.55 & 0.26 & 0.13 & 0.03 \\
\hline Training & 0.82 & - & 0.47 & 0.23 & 0.05 \\
\hline High School & 0.38 & 0.69 & - & 0.50 & 0.12 \\
\hline Postsecondary & 0.19 & 0.35 & 0.75 & - & 0.23 \\
\hline University & 0.04 & 0.08 & 0.17 & 0.34 & - \\
\hline \multicolumn{6}{|l|}{ Cohabitation } \\
\hline No training & - & 0.88 & 0.44 & 0.25 & 0.05 \\
\hline Training & 1.10 & - & 0.50 & 0.28 & 0.06 \\
\hline High School & 0.55 & 0.62 & - & 0.56 & 0.12 \\
\hline Postsecondary & 0.31 & 0.35 & 0.70 & - & 0.22 \\
\hline University & 0.08 & 0.08 & 0.15 & 0.27 & - \\
\hline \multicolumn{6}{|c|}{ Quebec } \\
\hline \multicolumn{6}{|l|}{ Marriage } \\
\hline No training & - & 0.51 & 0.31 & 0.13 & 0.03 \\
\hline Training & 0.75 & - & 0.62 & 0.26 & 0.06 \\
\hline High School & 0.47 & 0.92 & - & 0.42 & 0.10 \\
\hline Postsecondary & 0.20 & 0.39 & 0.63 & - & 0.23 \\
\hline University & 0.05 & 0.09 & 0.15 & 0.34 & - \\
\hline \multicolumn{6}{|l|}{ Cohabitation } \\
\hline No training & - & 0.61 & 0.46 & 0.22 & 0.05 \\
\hline Training & 0.76 & - & 0.76 & 0.36 & 0.08 \\
\hline High School & 0.58 & 0.95 & - & 0.47 & 0.10 \\
\hline Postsecondary & 0.27 & 0.44 & 0.58 & - & 0.22 \\
\hline University & 0.06 & 0.10 & 0.13 & 0.27 & - \\
\hline \multicolumn{2}{|c|}{ Hypergamy parameter } & 0.396 & & & \\
\hline \multicolumn{2}{|c|}{ Hypergamy parameter*cohabitation } & -0.179 & & & \\
\hline
\end{tabular}

Source: Census (PUMF) 2001

level of intermarriage occurs between adjacent educational groups and that the fourth barrier, between postsecondary education and a university degree, is the most difficult to cross in both regions and both types of union. ${ }^{13}$ This result is in line with previous research (for example Mare 1991; Schwartz and Mare 2005) showing that university graduates tend to be the most selective and closed group on the marriage - and in this case also on the cohabitation - market. For example, spouses have 2.2 times and cohabitors 2.6 times higher odds of crossing the third barrier than the fourth in English Canada (odds ratio for spouses: 0.50/0.23

13. For example, for married women in English Canada, the odds of crossing the first educational barrier are 0.82 , the odds of crossing the second barrier are 0.69 , the odds of crossing the third barrier are 0.75 , and the odds of crossing the fourth barrier are 0.34 . 
$=2.17$; odds ratio for cohabitors 0.56/0.22 $=2.55$ ). In French Canada, married couples have 1.8 times and cohabiting unions 2.1 times higher odds of crossing the third barrier than the fourth (odds ratio for spouses: $0.42 / 0.23=1.83$; odds ratio for cohabitors: $0.47 / 0.22=2.14$ ) .

To facilitate the interpretation, the odds of crossing an educational barrier are plotted in Figures 3 and 4. As the crossing parameters are asymmetrical between sexes and as the parameters above the diagonal differ from those under the diagonal (see above), gender-specific chances to marry or cohabit up the educational hierarchy are presented separately. Technically, this means that the crossing parameters from the portion of the table above the main diagonal are assigned to men and that the women's odds of crossing an educational barrier are derived from the portion under the main diagonal.

Figures 3 and 4 suggest four major findings. First, women in both English and French Canada have higher odds of upward educational mo-

Figure 3. Odds of Crossing Education Barrier up in Marriage and Cohabitation, Men and Women in English Canada

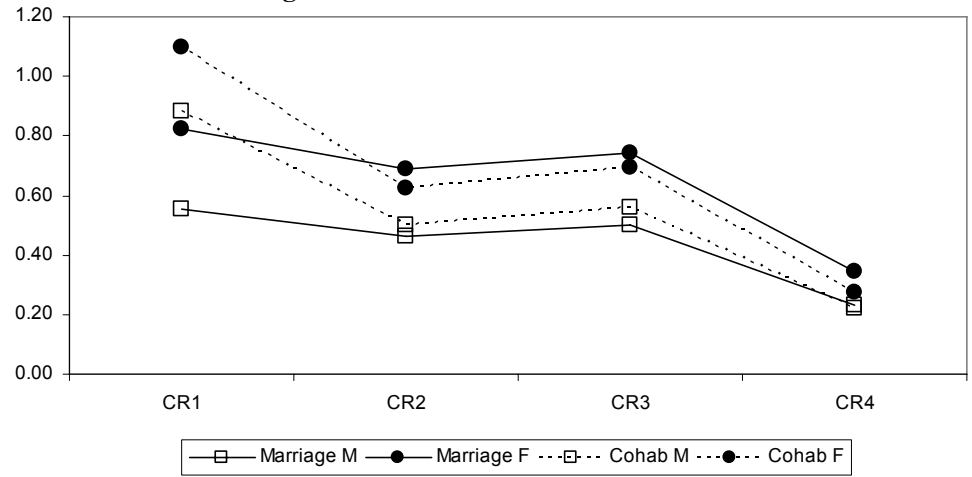

Figure 4. Odds of Crossing Education Barrier up in Marriage and Cohabitation, Men and Women in French Canada

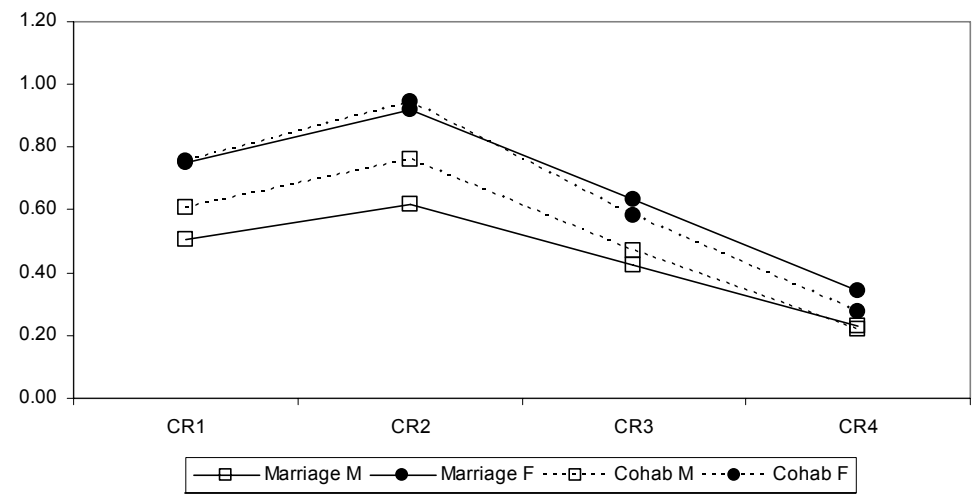


bility than men, and married women tend to have higher odds of partnering up than cohabiting women (except for the lowest educational barrier in English Canada). Second, married men have the lowest odds of upward educational mobility among all the groups considered. Third, cohabiting men and women are more alike than spouses in terms of upward mobility; cohabiting women have lower odds of upward mobility than married women, while cohabiting men have higher odds of partnering up then married men. Fourth, we cannot conclude that Quebec cohabitors are more similar to spouses than those in English Canada. Even though the three-way interaction effects between crossing*union*region were significant for the first three barriers, the relative differences, their size, and direction were different for each barrier (see Figure 5). For example, the difference between marriage and cohabitation in the odds of crossing the first educational barrier is much larger in English than in French Canada. The Quebec cohabitors have 20\% higher odds of crossing this barrier than their married counterparts $(0.61 / 0.51=1.20)$, whereas cohabitors in the rest of Canada have $60 \%$ higher odds of doing so than married couples $(0.88 / 0.55=1.60)$. This result supports our initial hypothesis about relative similarity of married and cohabiting couples in the French province. However, the finding is opposite for the second barrier (married and cohabiting couples are more similar in odds of overcoming the second educational barrier in English Canada than in Quebec; see Figure 5).

As for other findings, we must note that the curves for married and unmarried couples have relatively similar shapes (compare Figures 3 and 4). Men and women become more selective as they achieve higher education and the odds of crossing a barrier then decline as we move

Figure 5: Odds ratios of crossing educational barrier in English and French Canada (cohabitaton versus marriage) $^{*}$

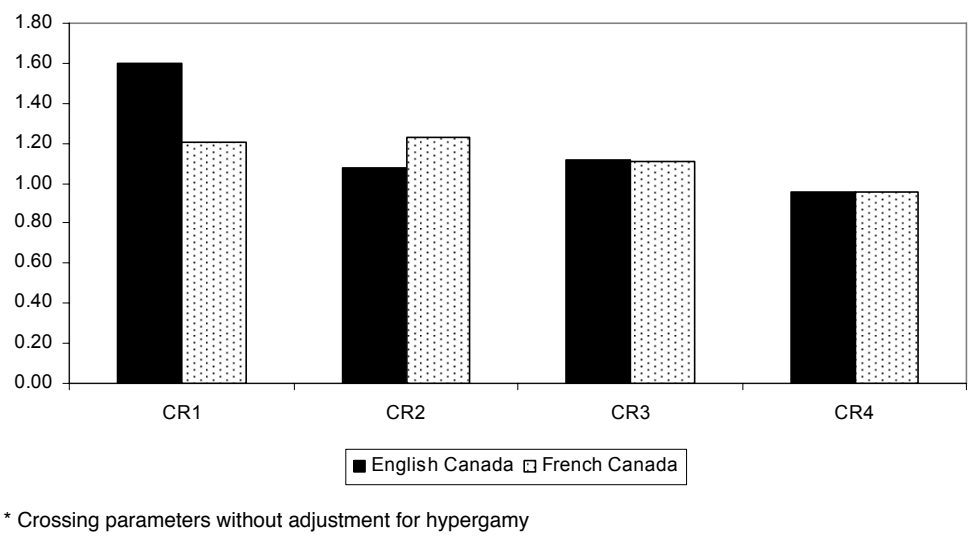


up through the educational ladder. In English Canada, crossing the first educational barrier that separates individuals having no formal training and those having some formal training but not a high school degree constitutes by far the easiest transition and this finding applies to both types of union. In French Canada, the same conclusion applies to the second educational barrier.

The analysis of the estimated crossing parameters does not support our first hypothesis predicting systematic differences in the interpartnering of married and unmarried couples in Quebec, as opposed to those living elsewhere in Canada. The three-way interaction effect between crossing*union*region is not significant for the fourth barrier and is negligible for the third barrier. Large and statistically significant differences were detected only for the first two educational barriers. However, they do not unambiguously point to higher similarity in terms of interpartnering between married and cohabiting couples living in Quebec. While Quebec spouses and cohabitors seem to be more alike with respect to crossing the first barrier when compared to their counterparts living elsewhere in Canada, the opposite is true of the second educational barrier.

\section{Conclusions}

The goal of this article was to contribute to research on educational assortative mating and evaluate the relative differences between marriage and cohabitation in terms of partner's selection. Most of current research on the assortative mating of married and unmarried couples comes from the United States (Blackwell and Lichter 2004, 2000; Schoen and Weinick 1993; Jepsen and Jepsen 2002) and little is known about these patterns in Canada. This is true despite the fact that educational homogamy partly determines the amount of resources available to families and households, contributes to the overall levels of social inequality within societies, and influences the life opportunities of the next generations (Mare 2000; Mare and Schwartz 2006; Esping-Andersen 2007; Jepsen and Jepsen 2002; Kalbach 2002; Richard 1991). This study aimed to fill this gap in research and investigated the relative similarity (or dissimilarity) of educational assortative mating among young married and cohabiting Canadian couples in 2001.

Our research was informed by two theoretical perspectives that make distinct predictions about relative differences in educational homogamy among married and unmarried couples. The double-selection hypothesis views cohabitation as a trial period before marriage and predicts higher educational homogamy among married rather than unmarried couples 
(Blackwell and Lichter 2004, 2000). The utilitarian theory (or "looser bond" approach) views cohabitation mainly as an alternative to marriage and explains conditions under which couples are likely to stay together without a marriage contract. In contrast to the former approach, it predicts higher educational homogamy among unmarried couples (Schoen and Weinick 1993).

We hypothesized that the demographic differences separating Quebec and the rest of Canada should be reflected in distinct patterns of assortative mating (for the demographic differences see Le Bourdais and Lapierre-Adamcyk 2004; Le Bourdais and Marcil-Gratton 1996). First, we expected to find smaller gap between married and unmarried couples in Quebec than in the rest of Canada (Hypothesis 1). Second, given the distinct roles that cohabitation plays in English and French Canada, we suggested the double-selection hypothesis as an appropriate theoretical perspective for Canada outside of Quebec and the utilitarian perspective as useful for the French province. Specifically, we predicted that married couples - compared to unmarried - would display relatively higher levels of educational homogamy in English Canada and lower levels of homogamy in Quebec (Hypothesis 2). Furthermore, we expected that the size of the gap between marriage and cohabitation would vary across educational groups. We also reasoned that our analysis should not be limited to homogamy measures but also look at the assortative mating of those who deflect the rule of homogamy, i.e., heterogamous couples.

Our hypotheses were tested by log-linear models using the Public Use Microdata File (PUMF) on Families from the 2001 Census. The analysis was restricted to young couples, i.e., those in which the woman is aged 25-34 and the age difference between partners is no more than 10 years.

The analyses do not support the first prediction about the relative similarity of married and unmarried couples in Quebec in terms of educational assortative mating. Our findings show that even though married and unmarried couples display different mating patterns, the relative gap separating the two groups is similar in both Canadian regions. This holds true whether we measure homogamy (i.e., tendency to marry and cohabit within one's own educational group) or relative social distance (i.e., probability of partnering outside one's own educational group).

The analyses also do not confirm our second hypothesis concerning the relative prevalence of homogamy. We found that married couples living in both English and French Canada generally display higher levels of educational homogamy than cohabiting partners. Our results are not directly comparable to those of other Canadian studies, but similar results were reported for the United States by Blackwell and Lichter (2000) and Jepsen and Jepsen (2002). 
The finding of higher educational homogamy among married couples corroborates the plausibility of the double-selection hypothesis which presumes that the "good" (meaning homogamous) matches marry while the others separate or keep cohabiting. Past research also showed that even "serious" cohabiting relationships with children are less stable than marriages in both English and French Canada (Le Bourdais and LapierreAdamcyk 2004). This finding, joined with lower educational homogamy, may indicate that common law unions tend to be of lower quality.

Further, we inspected the relative distance separating the various educational groups. In line with previous research in Canada (Hou and Myles 2007), we showed that intermarriage mainly, but not exclusively, takes place between adjacent educational levels. Our analysis suggested that while married and unmarried couples do not differ in the odds of overcoming the fourth educational barrier and display negligible differences in crossing the third barrier, they do not have the same propensity to overcome the first two educational barriers. However, Quebec married and cohabiting couples do not appear to be more similar in this regard than their counterparts living elsewhere in Canada. In both parts of the country, married men have the lowest odds of marrying up while married women have the highest odds of doing so (the only exception was found in the lowest educational barrier in English Canada).

Past studies have shown that marriage and cohabitation are more similar in the French-speaking province than in English Canada with regard to several characteristics, such as childbearing and childrearing or union stability (Le Bourdais and Lapierre-Adamcyk 2004). We cannot, however, conclude that this is also the case when considering educational assortative mating. A possible reason is that at the beginning of the 21st century, English Canada is "catching up" with Quebec in terms of the role and meaning of cohabitation. Another explanation for this null finding is that the cohabiting unions observed in census form a rather heterogeneous group in terms of meaning and duration of the union, for which we cannot control. As cohabitation becomes more common and widely accepted in society, two opposite processes may occur. On one hand, the number of cohabitors who live in a serious long-term relationship may increase because some couples, who would marry in a more traditional context, now cohabit. On the other hand, as cohabitation becomes more "normal" and less stigmatized, it may become a substitute for dating relationships, as some couples move in without intending to create a life-long relationship or raise a family. In this case, the number of short-term cohabiting unions will also increase.

In the future, we would like to expand our analysis and test additional conditions that might remain hidden. First, we would like to study 
whether and in what direction the differences between married and unmarried couples have evolved over time. Second, we would like to test our results by using different age groups in order to see whether our results were influenced by the imposed age restrictions. Furthermore, we would like to compare couples living with and without children as the relationships involving children are likely to be longer term and more stable than those without children. This approach could also shed some light on the issue of whether cohabitation has or not become an alternative to marriage. We would also like to introduce an ethnic dimension in the analysis of assortative mating. Here, we are interested in studying the evolution of barriers between ethnic groups and the extent to which this dimension interacts with other features of assortative mating process, such as education.

\section{REFERENCES}

Agresti, Alan. 2002. Categorical Data Analysis. New York: Wiley-Interscience.

Axinn, William G. and Arland Thornton. 1992. The relationship between cohabitation and divorce: Selectivity or causal influence? Demography 29:357-374.

Blackwell, Debra L. and Daniel T. Lichter. 2000. Mate selection among married and cohabiting couples. Journal of Family Issues 21:275-301. 2004. Homogamy among dating, cohabiting, and married couples. The Sociological Quarterly 45:719-737.

Blossfeld, Hans-Peter and Andreas Timm. 200. Educational systems as marriage markets in modern societies: A conceptual framework. In H.-P. Blossfeld and A. Timm, eds., Who Marries Whom? Educational Systems as Marriage Markets in Modern Societies. Dordrecht: Kluwer Academic Publisher.

Brines, Julie and Kara Joyner. 1999. The ties that bind: Principles of cohesion in cohabitation and marriage. American Sociological Review 64:333-355.

Erikson, Robert and John H. Goldthorpe. 1987. Commonality and variation in social fluidity in industrial nations. Part I: A model for evaluating the "FJH hypothesis. European Sociological Review 3:54-77.

Esping-Andersen, Gosta. 2007. Sociological explanations of changing income distribution. American Behavioral Scientist 50:639-658.

Hamplova, Dana. forthcoming. Educational homogamy among married and unmarried couples in Europe: Does context matter? Journal of Family Issues.

Hou, Feng and John Myles. 2007. The changing role of education in the marriage market: Assortative marriage in Canada and the United States since 
the 1970s. In Analytical Studies Branch Research Paper Series. Ottawa: Statistics Canada (accessed June 22, 2007).

Inglehart, Ronald. 1990. Cultural Shift in Advanced Industrial Society. Princeton, NJ: Princeton University Press.

Jepsen, Lisa K. and Christopher A. Jepsen. 2002. An empirical analysis of the matching patterns of same-sex and opposite-sex couples. Demography 39:435-453.

Johnson, Robert A. 1980. Religious Assortative Marriage in the United States. New York: Academic Press.

Kalbach, Madeline A. 2002. Ethnic intermarriage in Canada. Canadian Ethnic Studies 34:25-39.

Kalmijn, Matthijs. 1991a. Shifting boundaries: Trends in religious and educational homogamy. American Sociological Review 56:786-800. 1991b. Status homogamy in the United States. American Journal of Sociology $97: 496-523$.

1998. Intermarriage and homogamy: Causes, patterns, trends. Annual Review of Sociology 24:395-421.

Kass, Robert E. and Adrian E. Raftery. 1995. Bayes factors. Journal of the American Statistical Association 90:773-795.

Kuha, Jouni. 2004. AIC and BIC: Comparison of assumptions and performance. Sociological Methods Research 33:188-229.

Le Bourdais, Céline, and Évelyne Lapierre-Adamcyk. 2004. Changes in conjugal life in Canada: Is cohabitation progressively replacing marriage? Journal of Marriage and Family 66:929-942.

Le Bourdais, Céline, and Nicole Marcil-Gratton. 1996. Family transformation across the Canadian/American border: When the laggard becomes the leader. Journal of Comparative Family Studies 27:415-436.

Mare, Robert D. 1991. Five decades of educational assortative mating. American Sociological Review 56:15-32. 2000. Assortative mating, intergenerational mobility, and educational inequality. In California Center for Population Research On-Line Working Series. Los Angeles: California Center for Population Research.

Mare, Robert D. and Christine R. Schwartz. 2006. Educational assortative mating and the family background of the next generation. Sociological Theory and Methods 21:253-278.

Powers, Daniel A. and Yu Xie. 2000. Statistical Methods for Categorical Data Analysis. San Diego: Academic Press.

Qian, Zhenchao. 1998. Changes in assortative mating: The impact of age and education, 1970-1990. Demography 35:279-292.

Qian, Zhenchao and Samuel H. Preston. 1993. Changes in American marriage, 1971-1987: Availability and forces of attraction by age and education. American Sociological Review 58:482-495. 
Raftery, Adrian. 1995. Bayesian model selection in social research. Sociological Methodology 25:111-163.

Richard, Madeline A. 1991. Ethnic Groups and Marital Choices. Vancouver: UBC Press.

Schoen, Robert, and Robin M. Weinick. 1993. Partner choice in marriage and cohabitation. Journal of Marriage and Family 55:408-414.

Schwartz, Christine R. and Robert D. Mare. 2005. Trends in educational assortative marriage from 1940 to 2003. Demography 42:621-646.

Smits, Jeroen. 2003. Social closure among the higher educated: Trends in educational homogamy in 55 countries. Social Science Research 32:251-277.

Smits, Jeroen, Wout Ultee, and Jan Lammers. 1998. Educational homogamy in 65 countries: An explanation of differences in openness using countrylevel explanatory variables. American Sociological Review 63:264-285. 1999. Occupational homogamy in eight countries of the European Union, 1975-89. Acta Sociologica 42:55-68.

2000. More or less educational homogamy? A test of different versions of modernization theory using cross-temporal evidence for 60 countries. American Sociological Review 65:781-788.

Surkyn, Johan and Ron Lesthaeghe. 2004. Value orientations and the second demographic transition (SDT) in northern, western, and southern Europe: An update. Demographic Research S3:45-86.

Ultee, Wout, and Ruud Luijkx. 1990. Educational heterogamy and father-to-son occupational mobility in 23 industrial nations: General societal openness or compensatorystrategies of reproduction. European Sociological Review 6:125-149.

Van de Kaa, Dirk. 1993. Second demographic transition revisited: Theories and expectations. Pp. 81-126 in G.C.N. Beets, ed., Population and Family in the Low Countries 1993. Lisse: Swets and Zeitlinger.

Dana Hamplová graduated with a Ph.D. in Sociology from the Faculty of Arts and Philosophy at the Charles University (Prague, the Czech Republic) and in 2006 obtained a postdoctoral fellowship at McGill University at the Department of Sociology. In 2008, she obtained the Otto Wuchterle award from the Czech Academy of Sciences. Her work focuses on comparative research, social demography, and topics related to social stratification. Her works are published in a variety of books and journals.

Céline Le Bourdais is professor in the Department of Sociology at McGill University, where she holds a Canada Research Chair in Social Statistics and Family Change, and the academic director of the Quebec Interuniversity Centre for Social Statistics (QICSS). She has a long experience of longitudinal data analysis applied to the study of family. Her research, published in several scientific venues, examines the repercussions of recent demographic changes on the family histories of men, women, and children. 